\title{
Late Holocene vegetation changes in relation with climate fluctuations and human activity in Languedoc (southern France)
}

\author{
J. Azuara ${ }^{1}$, N. Combourieu-Nebout ${ }^{1}$, V. Lebreton ${ }^{1}$, F. Mazier ${ }^{2}$, S. D. Müller ${ }^{3}$, and L. Dezileau ${ }^{4}$ \\ ${ }^{1}$ UMR 7194 CNRS, Histoire naturelle de l'Homme Préhistorique, Département de Préhistoire, \\ Muséum national d'histoire naturelle, Paris, France \\ ${ }^{2}$ UMR 5602 CNRS, Géode, Université Toulouse-2 Jean Jaurès, Toulouse, France \\ ${ }^{3}$ Institut des Sciences de l'Evolution (ISE-M), Université Montpellier-2, Montpellier, France \\ ${ }^{4}$ UMR 5243 CNRS, Géosciences Montpellier, Université de Montpellier, Montpellier, France
}

Correspondence to: J. Azuara (jazuara2@mnhn.fr)

Received: 6 August 2015 - Published in Clim. Past Discuss.: 1 September 2015

Revised: 30 November 2015 - Accepted: 5 December 2015 - Published: 21 December 2015

\begin{abstract}
Holocene climate fluctuations and human activity since the Neolithic have shaped present-day Mediterranean environments. Separating anthropogenic effects from climatic impacts to better understand Mediterranean paleoenvironmental changes over the last millennia remains a challenging issue. High-resolution pollen analyses were undertaken on two cores from the Palavasian lagoon system (Hérault, southern France). These records allow reconstruction of vegetation dynamics over the last 4500 years. Results are compared with climatic, historical and archeological archives. A long-term aridification trend is highlighted during the late Holocene, and three superimposed arid events are recorded at 4600-4300, 2800-2400 and 1300-1100 cal BP. These periods of high-frequency climate variability coincide in time with the rapid climatic events observed in the Atlantic Ocean (Bond et al., 2001). From the Bronze Age $(4000 \mathrm{cal} \mathrm{BP})$ to the end of the Iron Age (around 2000 cal BP), the spread of sclerophyllous taxa and loss of forest cover result from anthropogenic impact. Classical Antiquity is characterized by a major reforestation event related to the concentration of rural activity and populations in coastal plains leading to forest recovery in the mountains. A major regional deforestation occurred at the beginning of the High Middle Ages. Around $1000 \mathrm{cal} \mathrm{BP}$, forest cover is minimal while the cover of olive, chestnut and walnut expands in relation to increasing human influence. The present-day vegetation dominated by Mediterranean shrubland and pines has been in existence since the beginning of the 20th century.
\end{abstract}

\section{Introduction}

Global climate projections (IPCC, 2014) show that the Mediterranean will be significantly impacted by 21 st-century temperature increases associated with a major drop in precipitation. The Mediterranean area is now included as one of the regions most sensitive to future climate change, especially concerning moisture availability. Consequences for Mediterranean environments will be particularly important since they have been largely modified by humans during the last millennia and are therefore very vulnerable even to weak influences. In this context, deciphering climatic and human causes of environmental changes is a crucial issue for understanding vegetation response to both forthcoming climate change and present land management policies.

Various Holocene climate archives are available from the Mediterranean and the Atlantic, such as marine ice-rafted debris in the North Atlantic (Bond et al., 2001), lake-level fluctuations in the Alps and the Mediterranean (Magny et al., 2002, 2013; Magny, 2004, 2013), glacier oscillations in the Apennines (Giraudi, 2004, 2005; Giraudi et al., 2011), lake isotope records from the whole Mediterranean basin (Roberts et al., 2008) and changes in storminess (Sorrel et al., 2009; Sabatier et al., 2012). They highlight important climatic variations during the latter half of the Holocene which are correlated with vegetation changes. Nevertheless, in the Mediterranean region, separating the impact of human activity from climate remains a challenging task (Roberts et al., 2011). During the mid-Holocene climate optimum, deciduous trees 
dominated the Mediterranean forest but after $5000 \mathrm{cal} \mathrm{BP}$, evergreen sclerophyllous taxa expanded and replaced the deciduous vegetation in many places (Reille and Pons, 1992; Jalut et al., 2000; Carrion et al., 2003; Sadori et al., 2011). This major vegetation change could be attributed either to climate change or human impact because during the same period farming spread across the northwestern Mediterranean region (Vaquer, 2010). Over the last millennia, environmental changes have resulted from interactions between climate and human activity, and there is no clear understanding of their respective influence (De Beaulieu et al., 2005).

The Languedoc is located in southern France under both Mediterranean and Atlantic climatic influences. Numerous archeological and historical records are available for this region, including archeobotanical studies valuable for assessing human impact on the environment (Durand, 2003; Chabal, 2007; Jorda et al., 2008; Cavero and Chabal, 2010; Figueiral et al., 2010). Various studies focus on the rural world in the Languedoc from the Neolithic to modern periods (Durand, 2003; Schneider et al., 2007; Gascò, 2010; Jallot, 2010; Janin, 2010; Ouzoulias, 2013). The variety of these archives may provide an extensive data set to compare climatic, archeological and historical records with the vegetation history in the Languedoc. Nonetheless, despite the existence of various Holocene pollen sequences in Languedoc such as those from Marsillargues (Planchais, 1982), Lez estuary (Planchais, 1987), Palavas (Aloïsi et al., 1978) and Embouchac (Puertas, 1998), Capestang is the only record which provides chronologically well-constrained high-resolution pollen data (Jalut et al., 2009).

This paper presents a new high-resolution composite pollen record from a sedimentary sequence recovered from the Palavasian wetland complex. The chronologically well-constrained pollen sequence documents the last 4500 years cal BP, from the final Neolithic to the present. This detailed study enables the identification of both climatic and anthropogenic impacts on vegetation dynamics. First, the comparison between this new vegetation record and climatic archives helps to identify the consequences of both long-term and multi-decadal climate variability for Mediterranean environments. Second, the detailed correlation with archeological and historical archives from the Languedoc region allows us to understand the link between vegetation history and land-use changes in historical and prehistorical times.

\section{Physical settings}

The Palavasian wetland complex is located on the southeastern French coast in the northwestern part of the Mediterranean Sea (Fig. 1). The complex consists of narrow lagoons, of $2 \mathrm{~km}$ width and between 4 and $8 \mathrm{~km}$ long, which run parallel to the shoreline and have shallow water depths (less than $1 \mathrm{~m}$ ). The lagoons are isolated from the sea by a continuous $150 \mathrm{~m}$ wide wave-produced sandy barrier.
The hydrographic network is composed of the Lez and Mosson rivers. The Lez flows directly into the sea, while the Mosson splits into two branches near the coast, one flowing into the lagoons and the other joining the Lez before its mouth. Their respective watershed is quite small $\left(653 \mathrm{~km}^{2}\right)$, extending over $50 \mathrm{~km}$ inland.

The climate is Mediterranean with a 4-month summer drought and mild and rainy winters. Mean temperature and rainfall are respectively $23^{\circ} \mathrm{C}$ and $26.2 \mathrm{~mm}$ in summer and $3.3^{\circ} \mathrm{C}$ and $58 \mathrm{~mm}$ in winter (Méteo France data, Montpellier Fréjorgues station).

The distribution of the main forest types classified by dominant taxa is drawn using vegetation maps from the IFN (Inventaire National Forestier, BD Forêt 1 (Fig. 1)). The regional vegetation forms altitudinal belts from the seashore to the southern part of the Massif Central (Cevennes range): the meso-Mediterranean belt is dominated by Quercus ilex and Pinus halepensis; the supra-Mediterranean belt is dominated by Quercus pubescens on limestone and by the introduced Castanea sativa on siliceous substrates; finally, the mountain belt is dominated by mixed forests of Abies alba and Fagus sylvatica. Pinewoods are present at all altitudes and are constituted by three main different species in the study area: $P$. halepensis forms extensive, mostly fireinduced pinewoods at low altitudes close to the coast, the endemic $P$. nigra subsp. salzmannii occupies restricted areas on dolomitic limestones in the Causse region, and $P$. sylvestris developed as a pioneer in the Cevennes range. Each Pinus species has its own ecological requirements and should respond differently to climatic changes. Unfortunately, these different species cannot be discriminated in routine pollen analysis, which complicates the interpretation of Pinus variations in terms of vegetation changes and climate changes. Halophytic vegetation is dominant in the vicinity of the coastal lagoons, mainly with Amaranthaceae such as Arthrocnemum macrostachyum, Sarcocornia fruticosa, Salicornia europaea, and Halimione portulacoides. The rivers supplying lagoons in freshwater are bordered by riparian forests composed of Alnus glutinosa, Fraxinus angustifolia, Populus alba, Populus nigra, and Ulmus minor. Finally, in the region, the Ericaceae are represented by an important diversity of species throughout the different altitudinal belt. The most frequent ones are Erica arborea, E. scoparia, E. multiflora, E. cinerea, Calluna vulgaris and Arbutus unedo.

\section{Materials and methods}

Pollen analyses were undertaken on two cores - EG08 (1.31 $\mathrm{m}$ long) and PB06 (7.71 $\mathrm{m}$ long) - recovered from the adjacent lagoons of Prevost and Pierre Blanche (Fig. 1). Eighty-eight pollen samples were analyzed from these two cores with a sampling resolution varying from 2 to $10 \mathrm{~cm}$. 


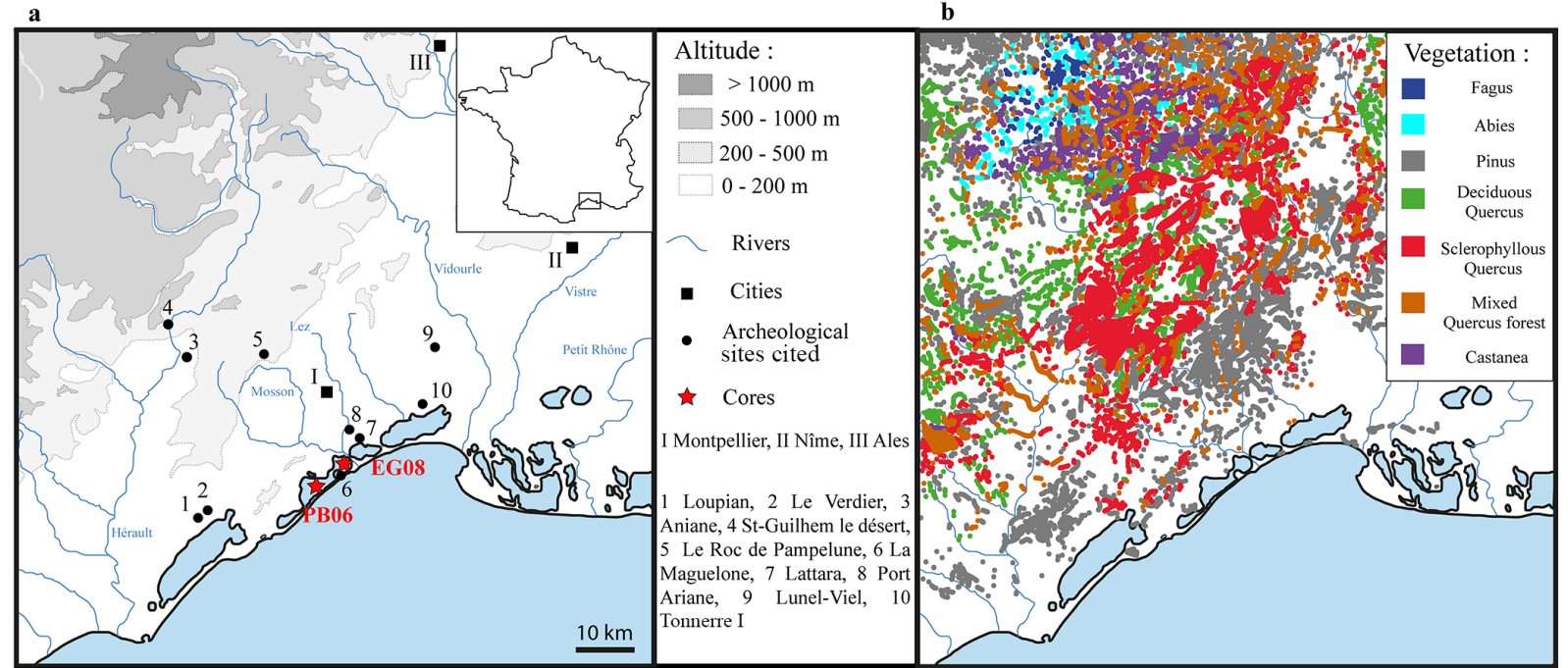

Figure 1. Geographical settings: (a) studied cores, main cities and rivers, topography, and archeological sites mentioned in the article; (b) vegetation map showing the distribution of forest types by dominant taxa (data from the National forestry inventory, IFN BD forêt 1).

\subsection{Lithology and sedimentation}

Previous sedimentological and geochemical analyses of both PB06 and EG08 cores highlight a clayey-silty sedimentation with shell fragments and intercalated fine layers of sandy material (Sabatier and Dezileau, 2010; Sabatier et al., 2012; Dezileau et al., 2011). The complete studied record covers the last 5 millennia from the mid-Holocene to the present day. During that time, the Palavasian complex was characterized by a lagoonal depositional environment with a recurrent marine influence through permanent connections with the sea. A major change in faunal content chronologically constrains the final closure between the lagoon and the sea at around $1000 \mathrm{cal} \mathrm{BP}(190-170 \mathrm{~cm}$ in PB06). From that time, the lagoon became more and more isolated.

Variations in marine mollusk abundance, granulometry and $\mathrm{Zr} / \mathrm{Al}$ and smectite / (illite + chlorite) ratios highlight three paleostorm events in core EG08 and eight in PB06. (Dezileau et al., 2011; Sabatier et al., 2012). The three more recent overwash layers recorded in both cores can be correlated between EG08 and PB06. They are identified as single storm events matching with historical storms documented and dated in historical archives to 1742, 1848 and 1893 (Dezileau et al., 2011). The fourth overwash layer recorded in PB06 is interpreted as another single storm event and the four older ones are interpreted as high storm activity periods (Fig. 2).

\subsection{Chronology and age model}

The PB06 age model was built using ${ }^{137} \mathrm{Cs},{ }^{210} \mathrm{~Pb}$ and AMS (accelerator mass spectrometry) ${ }^{14} \mathrm{C}$ dates on monospecific samples of Cerastoderma glaucum shells (Sabatier and Dezileau, 2010; Sabatier et al., 2012). ${ }^{14} \mathrm{C}$ ages were cor- rected according to reservoir age as defined by Sabatier et al. (2010) and then calibrated using the R-code package "clam" (Blaauw, 2010) and the Intcal09 calibration curve (Reimer et al., 2009) at 2 standard deviations (Sabatier et al., 2012). The whole core provides a high-resolution record over the last 7000 years; however, this particular study focuses only on the late Holocene period.

The EG08 age model has been developed by stratigraphic correlation with core PB06 (Dezileau et al., 2011). Core EG08 records the last 300 years and allows the reconstruction of a very high-resolution vegetation history during the modern period.

\subsection{Pollen analysis}

Pollen analyses performed on PB06 and EG08 are combined in a composite record: 13 samples in EG08 for the last 200 years cal BP and 75 samples in PB06 from 200 to $4600 \mathrm{cal}$ BP. The resulting average time between each samples is around 50 years for the whole sequence with variations from 10 to 100 years. There are two small gaps in the pollen sequence between 1555 and $1316 \mathrm{cal} \mathrm{BP}$ and between 622 and 202 cal BP (Fig. 2) because of insufficient pollen concentration in and below the storm sediments $\left(<5000\right.$ grains $\left.\mathrm{g}^{-1}\right)$.

Pollen extraction followed a standard method modified from Faegri and Iversen (1989). For each sample, $1 \mathrm{~g}$ of sediment was sieved through a 250 and $5 \mu \mathrm{m}$ mesh and then processed with $\mathrm{HCl}$ and $\mathrm{HF}$ for mineral digestion and sodium polytungstate for density separation. One tablet with a known amount of Lycopodium spores was added to estimate pollen concentration (Stockmarr, 1971). Pollen counts were performed at $\times 400$ magnification though pollen grains were identified at $\times 1000$ magnification with pollen keys (Punt, 


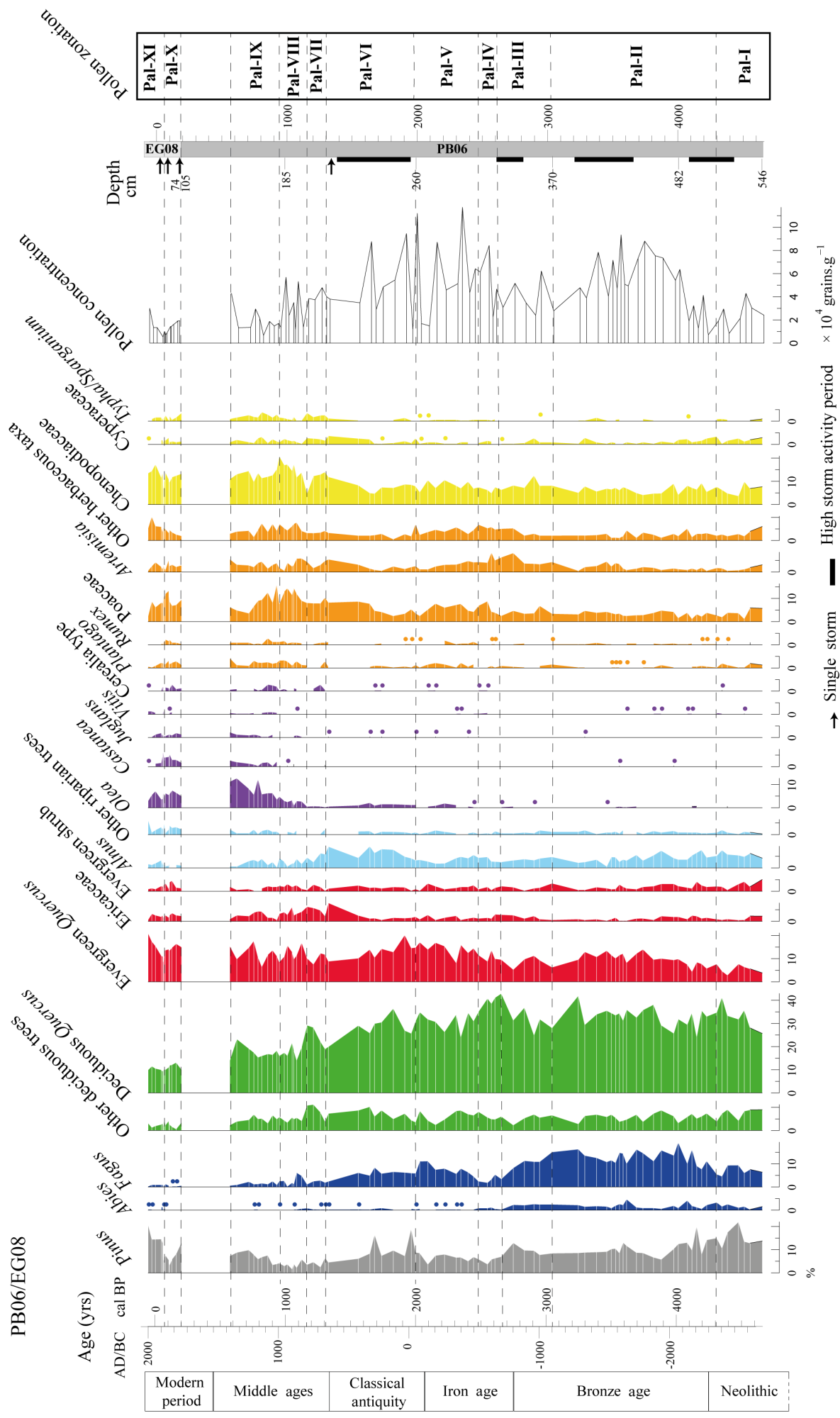

Figure 2. Pollen diagram of the cores PB06 and EG08. Pollen curves are presented in calendar year BP (correspondence between age and depth is presented on the left). The pollen zones are represented on the right of the diagram. 
1976; Beug, 2004) and atlases (Reille, 1992). A minimum pollen sum of 300 grains excluding Pteridophyta and nonpollen palynomorphs (NPP) was reached for each sample (Berglund and Ralska-Jaciewiczowa, 1986). Proportions of each taxon were calculated using the total sum of identified pollen grains without considering NPP and spores. The simplified pollen diagram (Fig. 2) was drawn using PSIMPOL (Bennett, 1992). The category "arboreal pollen" includes all the tree taxa except for the cultivated ones (Olea, Castanea and Juglans); the category "other deciduous trees" includes Acer, Ulmus, Betula, Carpinus and Corylus; the category "evergreen shrubs" includes Pistacia, Cistus and Buxus; and finally the category "other riparian trees" includes Fraxinus, Salix and Tilia. The ratio deciduous / evergreen Quercus was computed in order to be compared with results of previous studies (Jalut et al., 2009) and the ratio Fagus / deciduous Quercus in order to highlight covariation of these two taxa.

\section{Results}

\subsection{Pollen taphonomy}

Pollen concentration in the composite sequence is generally

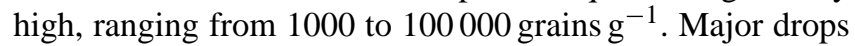
in pollen concentration with distorted pollen proportions are recorded in the three sandy overwash layers in EG08 and in the four layers corresponding to single storm events in PB06. Surprisingly the clayey layers just below these storm events also contain low pollen concentrations. It is assumed that during a storm event, the clayey surface sediments at the bottom of the lagoon were disturbed before the deposition of the sandy layer. This resulted in partial to total removal of the polleniferous material, with huge declines in pollen concentration through the sequence. Samples from the recent overwash layers in EG08 and PB06, identified as single storm events, represent sediments deposited within a few hours and naturally record no environmental information. Consequently, pollen analyses from these overwash layers and the samples from immediately underlying sediments

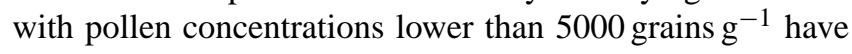
been discarded from the pollen record to avoid taphonomic perturbations. By contrast, no taphonomical issues are detected in the four older high storm activity periods in the lower part of PB06.

\subsection{Pollen transport vectors}

Alnus is the only riparian taxa which is well represented in the sequence, reaching almost $10 \%$ between 2000 and 1000 cal BP (Fig. 2). However, studies interested in quantifying the relative contribution of different taxa to the pollen rain show that Alnus is a high pollen producer (Broström et al., 2008). Therefore, it is unlikely that this taxa could represent the rivers contribution to Palavas pollen assemblages. The other riparian taxa display very low pollen proportions in present as in past pollen assemblages, in agreement with the small size of the Lez and the Mosson rivers (Fig. 2) and the position of the cores located far away from their mouths. This suggests that fluvial sources represent only a minor contribution to pollen assemblages. Moreover, despite the lagoons being continuously connected to the sea before $1000 \mathrm{cal} \mathrm{BP}$, no vegetation change is contemporaneous with the sandy barrier closure. Thus, even if a marine influence existed, it probably did not influence the pollen spectra with the exception of the storm events already discussed. Finally, the main pollen transport vector into the Palavasian lagoon system is assumed to be associated with wind.

\subsection{Vegetation history in the Palavas area}

The pollen record from the EG08 and PB06 cores illustrates vegetation dynamics over the last 5 millennia. Eleven pollen assemblage zones were visually determined, describing the sequence of vegetation changes (Table 1, Fig. 2).

Tree pollen (50-90\%) dominates the pollen spectra for almost the entire sequence, mainly comprising deciduous Quercus (10-40\%) associated with Pinus (1-20\%), evergreen Quercus (3-20\%) and Fagus in the lower part of the sequence (up to $20 \%$ ) (Fig. 2). Alnus is present in significant proportions (up to $10 \%$ ) as well as Abies (up to $3 \%$ ) at the base of the sequence.

Between 4700 and $4000 \mathrm{cal} \mathrm{BP}$, Pinus proportions decrease and the first occurrence of Cerealia-type pollen is recorded (Pal-I and first part of Pal-II, Fig. 2). Vitis is recorded sporadically throughout the sequence. After $4000 \mathrm{cal} \mathrm{BP}$, Fagus, Abies and the deciduous / evergreen Quercus ratio show a long-term downward trend (Figs. 2 and 3). Fagus displays several fluctuations superimposed on this overall decline. Fagus minima coinciding with deciduous Quercus maxima occur at 4600-4300 cal BP (Pal-I), 28002400 cal BP (Pal-III and Pal-IV) and 1300-1100 cal BP (PalVII) (Table 1, Fig. 2). Such oscillations are particularly highlighted by changes in the Fagus / deciduous Quercus ratio (events 3, 2 and 1 in Fig. 3). At $3300 \mathrm{cal} \mathrm{BP,} \mathrm{arboreal} \mathrm{pollen}$ proportions start to decline (85 to $70 \%$ ) (Pal-II, Fig. 3). Abies pollen disappears almost completely from the record around 2500 cal BP. Just before 2000 cal BP, arboreal pollen proportions rise sharply to their maximum (up to ca. $85 \%$ ). However, after 300 years, tree pollen abundance decreases again to $55 \%$ (Pal-III and IV, Fig. 3). Around $1300 \mathrm{cal} \mathrm{BP}$, a shortlived peak in deciduous Quercus interrupts this general decline (Pal-VII, Table 1, Fig. 2). After this brief reforestation event, forest decline begins again and appears more intense (Pal-VI, Fig. 3). Arboreal taxa reach their minimum $(45 \%$ of arboreal pollen) around $1000 \mathrm{cal} \mathrm{BP}$. While cultivated tree pollen such as Olea, Castanea and Juglans start to increase (Pal-VII, Fig. 3), Fagus disappears (Pal-VIII). At the same time, Ericaceae and herbaceous taxa including Poaceae (up to $15 \%$ ) and Cerealia-type pollen (up to $3 \%$ ), reach their highest values (Pal-VIII and Pal-IX, Table 1, Fig. 2). Dur- 
Table 1. Short description of the PB06 and EG08 pollen diagram zonation. Dates in the age columns (separated by slashes) represent upper and lower bounds of the zones. Negative dates refer to dates BC.

\begin{tabular}{|c|c|c|c|c|}
\hline Pollen zone & Interval (cm) & Age (year cal BP) & Age (year AD/BC) & Pollen zone signature \\
\hline Pal-XI & 33-0 (EG08) & $-62 / \sim 62$ & $\sim 2012 / 1888$ & $\begin{array}{l}\text { Fagus }(<1 \%) \text {, deciduous Quercus }(9-11 \%) \text {, sclero- } \\
\text { phyllous Quercus } \uparrow \text { (from } 11 \text { to } 21 \%), \text { Pinus } \uparrow \text { (from } \\
11 \text { to } 21 \% \text { ), Ericaceae } \downarrow \text { (from } 5 \text { to } 0.5 \% \text { ), Olea (3- } \\
7 \% \text { ), Castanea } \downarrow \text { (from } 5 \text { to } 0.5 \% \text { ), Poaceae } \downarrow \text { (from } 8 \\
\text { to } 2 \% \text { ), Chenopodiaceae }(11-17 \% \text { ) }\end{array}$ \\
\hline
\end{tabular}

\begin{tabular}{llll}
\hline Pal-X & $74-54($ EG08) $\sim 202 / 62$ & $\sim 1748 / 1888$ & Fagus $(<1 \%)$, deciduous Quercus $(10-13 \%)$, sclero-
\end{tabular}
phyllous Quercus (8-16\%), Pinus (3-13\%), Olea (4$10 \%)$, Castanea $\uparrow$ (from 1 to $7 \%$ ), Ericaceae (1-4\%), Poaceae and Chenopodiaceae (7-13\%)

\begin{tabular}{|c|c|c|c|c|}
\hline Pal-IX & 172-120 (РB06) & $\sim 892 / 622$ & $\sim 1058 / 1328$ & $\begin{array}{l}\text { Fagus low }(0.5-2.5 \%) \text {, deciduous Quercus (14-23\%), } \\
\text { sclerophyllous Quercus ( } 8-15 \%) \text {, Pinus } \uparrow \text { (from } 4 \text { to } \\
9 \% \text { ), Ericaceae (1-4\%), Olea } \uparrow \text { (from } 5 \text { to } 12 \% \text { ), } \\
\text { Poaceae } \downarrow \text { (from } 16 \text { to } 4 \% \text { ), Chenopodiaceae } \downarrow \text { (from } \\
20 \text { to } 10 \% \text { ) }\end{array}$ \\
\hline Pal-VIII & 210-172 (РB06) & $\sim 1192 / 892$ & $\sim 758 / 1058$ & $\begin{array}{l}\text { Fagus } \uparrow \text { and } \downarrow \text { (from } 1 \text { to } 6 \% \text { and from } 6 \text { to } 2 \% \text { ), decid- } \\
\text { uous Quercus } \downarrow \text { (from } 30-16 \% \text { ), sclerophyllous Quer- } \\
\text { cus }(8-17 \% \text { ), Pinus low (1-6\%), Olea } \uparrow \text { (from } 1 \text { to } \\
5 \% \text { ), Ericaceae ( } 3-6 \% \text { ) Poaceae } \uparrow \text { (from } 8 \text { to } 14 \% \text { ), } \\
\text { Chenopodiaceae } \uparrow \text { (from } 5 \text { to } 20 \% \text { ) }\end{array}$ \\
\hline Pal-VII & 220-210 (РB06) & $\sim 1316 / 1192$ & $\sim 634 / 758$ & $\begin{array}{l}\text { Fagus low }(2-3 \%) \text {, deciduous Quercus } \uparrow \text { (from } 19 \text { to } \\
28 \%) \text {, sclerophyllous Quercus }(7-12 \%) \text {, Pinus low (2- } \\
6 \%) \text {, Ericaceae }(2-6 \%) \text {, Poaceae }(8-10 \%) \text {, Chenopo- } \\
\text { diaceae }(12-14 \%)\end{array}$ \\
\hline Pal-VI & 260-220 (РB06) & $\sim 2000 / 1316$ & $\sim-50 / 634$ & $\begin{array}{l}\text { Fagus } \downarrow \text { (from } 8 \text { to } 2 \% \text { ), deciduous Quercus } \downarrow \text { (from } 30 \\
\text { to } 19 \% \text { ), sclerophyllous Quercus } \downarrow \text { (from } 20 \text { to } 8 \% \text { ), } \\
\text { Pinus } \downarrow \text { (from } 10 \text { to } 4 \% \text { ), Abies (<1\%), Ericaceae } \uparrow \\
\text { (from } 1 \text { to } 8 \% \text { ), Poaceae } \uparrow \text { (from } 3 \text { to } 8 \% \text { ), Chenopo- } \\
\text { diaceae } \uparrow \text { (from } 8 \text { to } 11 \% \text { ) }\end{array}$ \\
\hline Pal-V & 298-260 (РB06) & $\sim 2434 / 2000$ & $\sim-484 /-50$ & $\begin{array}{l}\text { Fagus } \uparrow \text { (from } 4 \text { to } 11 \%) \text {, deciduous Quercus }(24- \\
35 \%) \text {, sclerophyllous Quercus }(8-17 \%) \text {, Pinus (5- } \\
9 \%) \text {, Abies }(<1 \%) \text {, Chenopodiaceae and Poaceae low } \\
(5-10 \%)\end{array}$ \\
\hline Pal-IV & 322-298 (РB06) & $\sim 2643 / 2434$ & $\sim-693 /-484$ & $\begin{array}{l}\text { Fagus low }(2-5 \%) \text {, deciduous Quercus very high }(35- \\
42 \%) \text {, sclerophyllous Quercus }(9-14 \%) \text {, Pinus low }(7- \\
4 \%) \text {, Abies disappearance }(\leq 1 \%) \text {, Poaceae } \uparrow \text { (from } 2 \\
\text { to } 6 \% \text { ), Chenopodiaceae (around } 6 \% \text { ) }\end{array}$ \\
\hline Pal-III & 370-322 (РВ06) & $\sim 3038 / 2643$ & $\sim-1088 /-693$ & $\begin{array}{l}\text { Fagus } \downarrow \text { (from } 11 \text { to } 3 \% \text { ), deciduous Quercus } \uparrow \text { (from } \\
25 \text { to } 40 \% \text { ), sclerophyllous Quercus (5-9\%), Pinus } \\
\text { (8-13\%), Abies low }(2-3 \%) \text {, Poaceae low (3-7\%), } \\
\text { Chenopodiaceae (7-12\%) }\end{array}$ \\
\hline Pal-II & 514-370 (РB06) & $\sim 4350 / 3038$ & $\sim-2400 /-1088$ & $\begin{array}{l}\text { Fagus high (7-19\%), deciduous Quercus high and vari- } \\
\text { able (24-41\%), sclerophyllous Quercus low (6-14\%), } \\
\text { Pinus (from } 14 \text { to } 8 \%) \text {, Abies low (1-4\%), Poaceae } \\
\text { and Chenopodiaceae low }(2-9 \%)\end{array}$ \\
\hline Pal-I & 546-514 (РВ06) & $\sim 4694 / 4350$ & $\sim-2744 /-2400$ & $\begin{array}{l}\text { Fagus low (4-9\%), deciduous Quercus } \uparrow \text { (from } 25 \\
\text { to } 41 \%) \text {, sclerophyllous Quercus low }(3-7 \%) \text {, Pinus } \\
\text { variable }(10-22 \%) \text {, Abies low }(1-3 \%) \text {, Poaceae and } \\
\text { Chenopodiaceae low }(1-7 \%)\end{array}$ \\
\hline
\end{tabular}


ing the 19th century, arboreal pollen proportions remain relatively low $(\sim 50 \%)$ compared to the rest of the sequence and Castanea pollen percentages increase sharply (Pal-X, Table 1, Fig. 2). In the last 100 years Pinus and evergreen Quercus pollen become the dominant trees of the Mediterranean forest, while cultivated-tree abundances (Olea, Castanea and Juglans) decrease.

\section{Climate interpretation}

\subsection{The long-term aridity trend}

In the Mediterranean basin, the early and mid-Holocene are characterized by enhanced moisture and precipitation increases until $\sim 5000$ cal BP (Carrión, 2002; Fletcher et al., 2007; Magny et al., 2012) and are then followed by longterm aridification throughout the region, recorded by many proxies such as palynology, geochemistry, lake levels, semimobile dune systems and Saharan eolian dust (Zazo et al., 2005; Jalut et al., 2009; Pérez-Obiol et al., 2011; Roberts et al., 2011; Jiménez-Espejo et al., 2014; Jiménez-Moreno et al., 2015). This aridification trend has been linked to a decrease in summer insolation which could have resulted in lower sea-surface temperatures, reduced land-sea contrast and, thus, lower precipitation during the fall-winter season (Marchal et al., 2002; Jiménez-Moreno et al., 2015).

Between 4500 and $2000 \mathrm{cal} \mathrm{BP}$, the noteworthy occurrence and/or high abundance of Abies and Fagus pollen at the base of the Palavas pollen record suggests their presence close to the Palavasian lagoon (Fig. 2). The occurrence of Fagus at low altitude in southern France is also recorded in the Lez delta pollen sequence and in the Rhône valley anthracological record (Planchais, 1987; Delhon and Thiébault, 2005). It matches well with the mid-Holocene enhanced moisture recorded in the western part of the Mediterranean basin. In fact, Abies and Fagus are now found only in the mountainous hinterland, more than $70 \mathrm{~km}$ north of the lagoon (Fig. 1). Therefore, in the Palavasian pollen record, high percentages of Abies and Fagus before $2800 \mathrm{cal}$ BP may be linked to their broader expansion towards the south at lower elevations. Such a conclusion is corroborated by charcoal data recovered from coastal archeological contexts, indicating that (1) Fagus was present at ca. $3000 \mathrm{cal} \mathrm{BP}$ (Etang de l'Or Tonnerre I) and $2000 \mathrm{cal} \mathrm{BP}$ (Port Ariane) and (2) Abies was present at ca. 2000 cal BP (Lattara and Port Ariane) (Chabal, 2007; Jorda et al., 2008; Cavero and Chabal, 2010). These two species do not tolerate summer dryness and their expansion to lower altitudes in southern France implies that more humid conditions prevailed in the Languedoc at least locally (Quezel, 1979; Delhon and Thiébault, 2005).

From 4500 to $3000 \mathrm{cal}$ BP, Pinus declined steadily. This might express a range contraction toward the north in Pinus sylvestris associated with the onset of late Holocene aridification (Fig. 2). The parallel long-term downward trend expressed in the Abies and Fagus abundance curves from 3000 to 1000 cal BP clearly follows the Holocene long-term aridification (Figs. 2 and 3). At the same time, deciduous Quercus proportions remain very high around Palavas (Fig. 2). No clear decrease in Quercus is evidenced, which is inconsistent with results from other sites in the Languedoc. For instance, in the Capestang sequence, less than $100 \mathrm{~km}$ from Palavas, deciduous Quercus begins to decline at $4000 \mathrm{cal} \mathrm{BP}$ in correlation with an increase in evergreen Quercus (Jalut et al., 2009). Such a replacement of deciduous forest by sclerophyllous evergreen forest is lacking in Palavas at the same period, occurring only during the last century. The Capestang core was sampled in a wetland area with small ponds (Jalut, 1995). Considering the size of these ponds (around $100 \mathrm{~m}$ wide), the pollen record at this site probably documents a more local-scale vegetation history compared to the Palavas sequence with its much larger basin (around $2 \mathrm{~km}$ wide) (Sugita, 1993). Actually, in the Palavas region, the mountainous hinterland massifs might have favored the continuation of relatively humid conditions and hence the persistence of deciduous Quercus forests until the historical period. The same deciduous Quercus forests were disadvantaged in the plains surrounding Capestang, resulting in the absence of a deciduous Quercus pollen signal. A similar situation is recorded at Lake Scutari (Albania/Montenegro) where a strong altitudinal gradient, combined with sufficient moisture availability, favored the development of deciduous forest throughout the late Holocene (Sadori et al., 2014).

Around $2000 \mathrm{cal} \mathrm{BP}$, Abies almost disappears from the palynological record and definitively from the Languedoc lowlands, and Fagus persists up to $1000 \mathrm{cal} \mathrm{BP}$. Late Holocene climate changes have hence caused the northward range contraction in Abies, Fagus and probably also Pinus sylvestris towards their present-day mountainous location. These same changes favored the development of deciduous Quercus forests and Mediterranean pines at the studied location.

\subsection{Short-term climatic fluctuations}

Sharp decreases in Fagus pollen proportions coinciding with deciduous Quercus maxima occurred at 4600-4300, 28002400 and $1300-1100$ cal BP (Fig. 2) and are highlighted through sharp decreases in the Fagus / deciduous Quercus ratio (Fig. 3). Oscillations might be linked to repetitive $\mathrm{Fa}$ gus retreats toward higher altitudes coinciding with repeated expansions of deciduous Quercus close to Palavas at lower altitudes (Figs. 2 and 3). These decreases might also correspond to major drops in Fagus pollen productivity caused by enhanced environmental stresses. In the French mountainous area of the Mediterranean, Fagus is at the limit of its geographical range (Quezel, 1979), and it is therefore very sensitive to climatic variations, especially regarding moisture availability (Delhon and Thiébault, 2005). Since Fagus is less tolerant to dryness than deciduous Quercus, each fluctuation may be related to repeated arid episodes. 


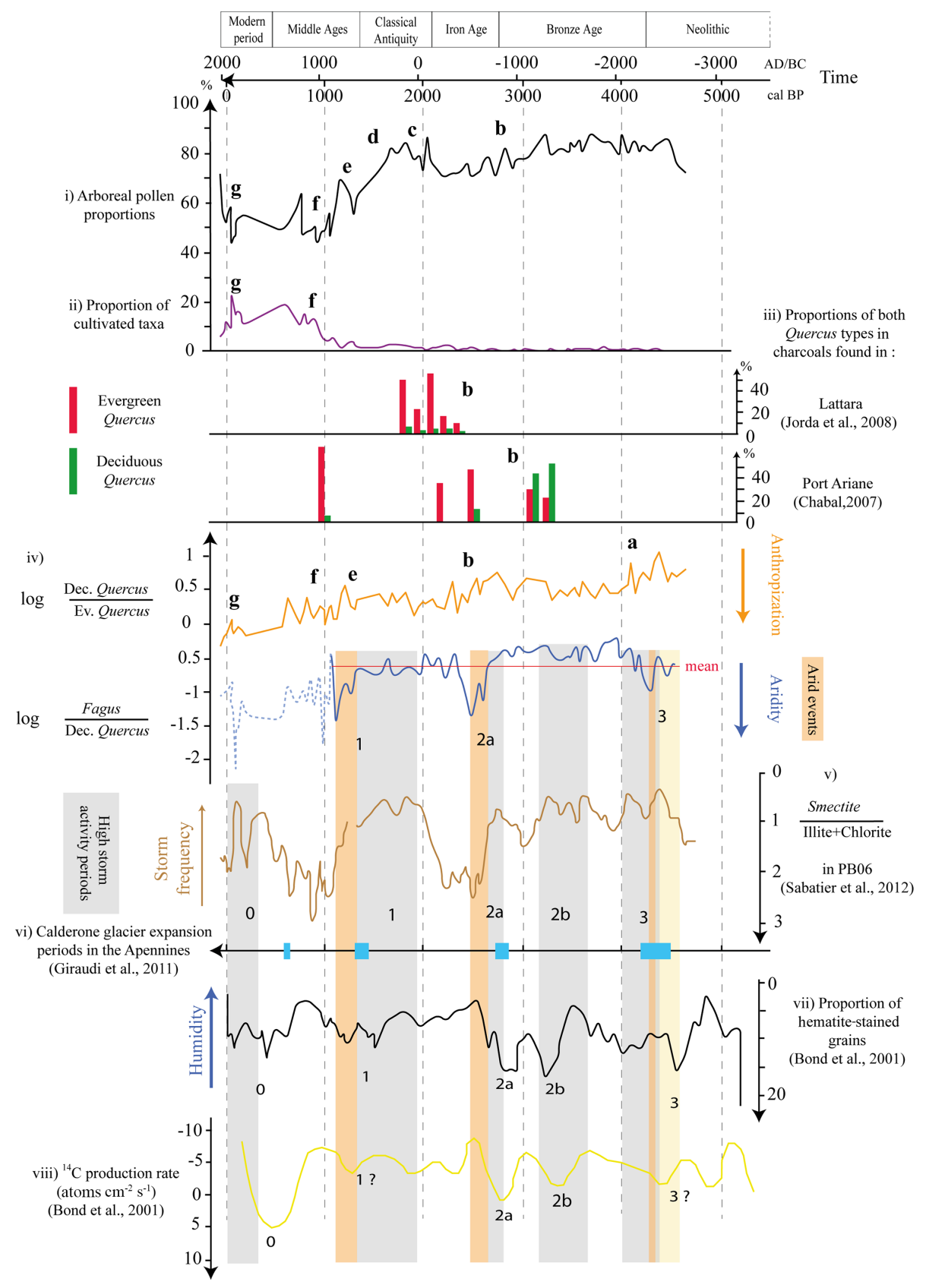

Figure 3. Comparison of the pollen data from the core PB06 and EG08 with anthracological and climatic data. Orange shaded bars represent arid events and grey shaded bars represent high storm activity periods: (i) arboreal pollen proportions; (ii) proportion of cultivated taxa; (iii) proportions of both Quercus type charcoals in Lattara and Port Ariane archeological sites; (iv) logarithm of deciduous / evergreen Quercus (orange) and Fagus / deciduous Quercus (blue) ratios (after $\sim 1100$ cal BP (10th century) the Fagus / deciduous Quercus ratio (dotted light blue line) cannot be interpreted in terms of climate fluctuations because of the strong human influence); (v) smectite / illite + chlorite ratio in the core PB06 (Sabatier et al., 2012); (vi) Calderone glacier expansion periods in the Apennines (the width of each blue box represent the estimated time during which the glacier expand (Giraudi et al., 2011)); (vii) proportion of hematite-stained grains in the cores MC-52/VM29-191 in the North Atlantic (Bond et al., 2001); (viii) ${ }^{14} \mathrm{C}$ production rate (Bond et al., 2001). 
Arid events have already been reported in the central and western Mediterranean from Lake Scutari (Albania/Montenegro) soon before 4000, around 2900 and around 1450 cal BP (Sadori et al., 2014) and in southwestern Spain at 4000, 3000-2500 and 1000 cal BP (JimenezMoreno et al., 2015). Discrepancies in the chronology of these events between sites are probably due to age model uncertainties. Furthermore, these arid events correspond in time to Calderone glacier extension phases in the Apennines around $4200 \mathrm{calBP}$, between 2855-2725 and 14101290 cal BP (Fig. 3) (Giraudi, 2004, 2005; Giraudi et al., 2011). They are also concurrent with the rapid vegetation and marine environment changes recorded in Mediterranean (e.g., Cacho et al., 2001; Fletcher et al., 2007; Frigola et al., 2007; e.g., Kotthoff et al., 2008; Schmiedl et al., 2010; Combourieu-Nebout et al., 2009, 2013; Desprat et al., 2013; Fletcher and Zielhofer, 2013). These climatic events fit with the general picture of climate change depicted by lake-level fluctuations in central Europe and the northern Mediterranean (Magny, 2013; Magny et al., 2013). Moreover, they are contemporaneous with North Atlantic Bond events around 4200, 2800 and $1400 \mathrm{cal} \mathrm{BP}$, underlining the efficient climatic coupling between the North Atlantic and the Mediterranean during the late Holocene (Fig. 3).

Variations in clay mineralogy in the core PB06 provide a proxy of past storm frequency in the Palavas region complementary to pollen data, which may give useful information to investigate mechanisms of these climatic oscillations (Sabatier et al., 2012). Arid events depicted by vegetation are contemporaneous with sharp variations in storminess. They occur during transition periods, before (event 3) or after (events 1 and 2) high storm activity periods (Fig. 3). Increases in storm frequency have been interpreted as periods during which westerlies, and thus storm tracks, were shifted to the south, bringing more precipitation to the Mediterranean. These situations are similar to persistent negative NAO-like periods (NAO - North Atlantic Oscillation) and may be caused by the southward displacement of the polar front linked to a weakening of the Atlantic meridional overturning circulation (AMOC) during colder periods (Dezileau et al., 2011; Trouet et al., 2012). Such an interpretation is consistent with the humidity recorded in PB06 during high storm activity periods and with the Calderone glacier expansion phases (Giraudi, 2004, 2005; Giraudi et al., 2011). Conversely arid events 2 and 1 might correspond to persistent positive NAO-like periods. According to this mechanism, these events might correspond to warmer periods with a decreasing storm frequency when westerlies and storm tracks are shifted to the north. The closeness in time of arid events 2 and 1 with respectively high storm activity periods $2 \mathrm{a}$ and 1 within the Bond event $2 \mathrm{a}$ and 1 time periods, suggests that these two Bond events might be divided in two phases, a humid one followed by an arid one. A similar schema is reported during older arid episodes, Heinrich events 4, 2 and 1 (Naughton et al., 2009). A two-phase pattern occurs within these three Heinrich events with a change from wet and cold to dry and cool conditions. The proposed mechanism involving the succession of opposite persistent NAO-like periods is very similar to the one developed for the late Holocene rapid climatic events (Trouet et al., 2012), despite Heinrich events being recorded in a glacial period. The arid event 3 remains more difficult to interpret because it seems contemporaneous with an increase in storminess. However, it is difficult to define its lower boundary because it is located at the bottom of the sequence. Further analyses are needed to determine properly its chronological extension and link to high storm activity periods.

Bond events have been correlated with fluctuations in ${ }^{14} \mathrm{C}$ production rate, suggesting a solar forcing (Bond et al., 2001) (Fig. 3). However, no exceptional residual ${ }^{14} \mathrm{C}$ excursions are depicted around 4200 and $1400 \mathrm{cal}$ BP and the variability in solar activity cannot explain all the observed changes (Debret et al., 2007; Sabatier et al., 2012). Wavelet analysis performed on Bond et al. (2001) IRD (ice-rafted debris) time series and other marine paleoclimatic proxies highlights three major climate cyclicities: 1000,1500 and 2500 years. The two cyclicities of 1000 and 2500 years are solar related, while the 1500-year climate cycles, dominant during the second part of the Holocene, appear to be clearly linked with the oceanic circulation (Debret et al., 2007). In the Mediterranean, the succession of stormy or humid periods and arid events close in time within some Bond events time periods brings new aspects to characterizing late Holocene climatic oscillations that should be taken into account in future attempts to understand the mechanisms involved in climate variability.

\section{Anthropogenic impact on vegetation}

\subsection{Ecological significance of evergreen Quercus development during the late Holocene in southern France}

During the late Holocene, in the northwestern Mediterranean, sclerophyllous evergreen forest development has been controversially interpreted either as an effect of late Holocene aridification (Jalut et al., 2000, 2009) or as a consequence of increasing anthropogenic impact (Triat-Laval, 1978; Planchais, 1982; Reille, 1992; Tinner et al., 2009; Henne et al., 2015).

In the Palavas record the deciduous/evergreen Quercus ratio displays a regular decrease through the sequence, which could result from the late Holocene aridification trend (Fig. 3). However, after $2000 \mathrm{cal}$ BP, deciduous and evergreen Quercus forests both decline at the same time. This simultaneous decline of evergreen and deciduous Quercus is not consistent with variations driven by the increasing aridity. Moreover, no correlation can be found between increases in evergreen Quercus proportions and the short arid events discussed before (Figs. 2 and 3) which conversely correspond 
to deciduous Quercus increases. The transition from deciduous to evergreen forest is not clearly recorded in Palavas before the last century. Therefore, climate variability alone cannot explain the evergreen Quercus dynamic around the Palavasian wetland complex, and other factors have to be considered.

\subsection{Influence of human societies on forest composition before Classical Antiquity}

At the end of the Neolithic, between 4500 and $4000 \mathrm{cal}$ BP, the decrease in the deciduous/evergreen Quercus ratio might be the first evidence of anthropogenic impact on Mediterranean forest composition (Pal-I in Fig. 2 and event a in Fig. 3). In fact, more than 100 small villages were present during this period in the Palavas region (Jallot, 2011). Farming societies were very wealthy and dynamic, with a higher influence and control of the environment than during previous periods (Jallot, 2010). The increase in agricultural activity may thus have favored the evergreen Quercus, a tree taxon which is especially resilient to high-frequency disturbances (Barbero et al., 1990).

After $3300 \mathrm{cal} \mathrm{BP}$, at Port Ariane (Chabal, 2007) and Tonnerre I (Cavero and Chabal, 2010), the anthracological records display higher abundances of evergreen Quercus in comparison to the Palavas pollen data (Figs. 2 and 3). These results illustrate the overrepresentation of evergreen Quercus in the areas surrounding human settlements during the Bronze Age and confirm that evergreen Quercus forests were already favored by humans.

Between 2800 and $2000 \mathrm{cal} \mathrm{BP}$, the deciduous / evergreen Quercus ratio decreases again (event b in Fig. 3). At that time, evergreen Quercus dominates the Port Ariane and Lattara anthracological assemblages (event b in Fig. 3) (Chabal, 2007; Jorda et al., 2008). Evergreen Quercus abundance around archeological sites reinforces the link between increases in evergreen Quercus pollen and the enhanced anthropogenic influence since $2800 \mathrm{cal} \mathrm{BP}$. These changes correspond to the Bronze Age-Iron Age transition, a crucial period in Languedoc prehistory. During the Iron Age, the coastal area around the Palavasian lagoons became an important trading area with Mediterranean civilizations. The development of Lattara city near the lagoon shores attests to the significant increase in human activity between 2500 and 2000 cal BP (Cavero and Chabal, 2010). Nevertheless, the second arid event recorded between 2800 and $2400 \mathrm{cal}$ BP in the Palavas sequence may have triggered forest changes or exacerbated human impact on vegetation. As well as changes in forest composition, human activity also began to affect forest cover through deforestation.

\subsection{Classical Antiquity}

During Classical Antiquity, the maximum expansion of forest recorded at Palavas (event $\mathrm{c}$ in Fig. 3) does not seem to fit with the widespread economic development in the Languedoc. However, settlement migration from the hinterland to the coast, beginning during the Iron Age, allowed forest expansion in the hinterland. Archeologists have observed a decrease in the number of small settlements in mountainous areas while the coastal cities such as Lattara expanded (Janin, 2010). Thus, during Classical Antiquity, most of the villae in this part of the Languedoc were located in coastal plains (Ouzoulias, 2013; carte archéologique nationale BD patriarche http://www. villa.culture.fr/\#/fr/annexe/ressources/t=Ressources). Therefore, the forest expansion possibly corresponds to forest recovery in the mountains, which were less densely populated at this time. Reforestation was probably also favored by enhanced humidity attested by the relative importance of Fagus in the deciduous forest (Fig. 2).

\subsection{Transition between Classical Antiquity and the early Middle Ages}

The collapse of the Roman Empire is generally considered to have been a major crisis of the rural world, leading to widespread land abandonment and reforestation (Kaplan, 1994). However, the Palavas pollen record clearly shows a major deforestation (event d in Fig. 3), which is consistent with the most recent historical and archeological studies carried out in the Languedoc but does not support the theory of a major crisis. Historians now interpret the decrease in villae (Roman farms) numbers at the end of Classical Antiquity as the result of an agrarian system transformation in the Gallia Narbonensis province. Numerous small villae were replaced gradually by larger ones, fewer in number but less vulnerable to economic hazards. At the beginning of the 5th century $(1550 \mathrm{cal} \mathrm{BP})$, while the number of villae sharply decreased in the Languedoc, important extensions of the Loupian villae (Fig. 1) are recorded on the lagoon shore (Schneider et al., 2007). Moreover, recent archeological excavations in this area have discovered a new type of rural housing which developed during the early Middle Ages on, and alongside, the former Roman territorial network. Two new settlements of this type were founded near abandoned villae in Lunel-Viel and Verdier between the 4th and the 5th centuries (Fig. 1) (Schneider et al., 2007). During the same period, the Roc de Pampelune village started to develop in the mountains where territories were free of human occupation during Classical Antiquity (Fig. 1) (Schneider et al., 2007). Finally, a new diocese was established in the 6th century on the island of La Maguelone (Fig. 1) (Schneider, 2008). In such a context of human occupation, the major deforestation event recorded at Palavas (Figs. 2 and 3) is consistent with the archeology, which provides evidence of a very dynamic rural world despite the collapse of the Roman Empire. 


\subsection{Crisis of the rural world?}

Following the major forest decline associated with the Classical Antiquity-early Middle Ages transition, significant reforestation occurred between 1300 and $1200 \mathrm{cal} \mathrm{BP}$ (650 and $750 \mathrm{cal}$ AD) (Pal VII in Fig. 2 and event e in Fig. 3). This event coincides with a gap in the archeological record between the 7th and the 8th centuries. In fact, during this period, many archeological settlements are abandoned in the Languedoc. For instance, Roc de Pampelune village and Dassargues farm, near Palavas, were abandoned between 1350 and $1300 \mathrm{cal} \mathrm{BP}(600$ and $650 \mathrm{cal}$ AD) while new settlements were founded in their vicinity approximately 100 years later (Schneider et al., 2007) (Fig. 1). For now, this settlement abandonment alone does not demonstrate a rural decline at this time (Schneider et al., 2007). On the other hand, the reforestation recorded in the Palavas pollen sequence attests to a major crisis during this period and confirms that human activity caused forest loss before the 7th century (Fig. 3). This reforestation is characterized by an important increase in most of deciduous-tree pollen proportions, including deciduous Quercus but excepting Fagus, which displays very low abundances related to the arid event 1 discussed previously (Fig. 2). In spite of the late Holocene aridification and the arid event 1, the increase in deciduous Quercus indicates that climatic conditions in the hinterland were still favorable to deciduous forest development except for Fagus.

\subsection{The High Middle Ages}

During the High Middle Ages (11th, 12th and 13th centuries), new types of human settlements are identified in the Languedoc (Durand, 2003; Schneider et al., 2007). Historical studies have identified 128 new fortified villages (castra) in the region with at least 8 of them within the watershed of the Palavasian lagoon. Thirty-three new (or innovative) rural settlements known by the term mansus, specifically located in or close to recently deforested areas, were located near Palavas. Two major abbeys were established at Aniane and St-Guilhem and developed intensive land-use practices. Feudal lords deforested river banks to extend their lands in order to grow cereals. At least 27 of these cereal fields were present along the Mosson and Lez rivers. Finally, the city of Montpellier was also established during this period and became an important city in France in the 13th century (Britton et al., 2007). These settlement expansions explain the major forest loss (event $\mathrm{f}$ in Fig. 3) and the evergreen shrubland extension (Fig. 2) recorded in the Palavas pollen record from 1150 to $850 \mathrm{cal}$ BP (from ca. 800 to $1100 \mathrm{AD}$ ). Historical and palynological studies both highlight the strong human influence on the environment during the High Middle Ages.

Just like during the reforestation of the 7th and 8th centuries, Fagus abundance changes around $1100 \mathrm{cal}$ BP are not consistent with variations in proportions of other forest taxa. Fagus is the only pollen taxa which displays a significant in- crease at this time (Fig. 2). Though Fagus may be affected at that time by human activity, the decorrelation between $\mathrm{Fa}$ gus signal and the anthropogenic vegetation changes reinforce the interpretation of Fagus as a good climate indicator until this approximate date. However, after $1100 \mathrm{cal} \mathrm{BP} \mathrm{Fa}$ gus proportions increasingly drop. Human impact on forest taxa is expected to be too strong and Fagus can no longer be used as an aridity proxy.

\subsection{Cultivated plants record}

The first evidence of Cerealia-type pollen recorded in the Palavas pollen sequence at $4400 \mathrm{cal} \mathrm{BP}$ (Fig. 2) is congruent with the Embouchac pollen record, attesting to cereal cultivation in the vicinity of the lagoon shores by Neolithic populations (Puertas, 1999) (Fig. 1). Later, during the Middle Ages (Fig. 2), the maximum of Cerealia-type pollen correlates with the strong anthropogenic impact associated with the cereal fields planted along the Mosson and Lez rivers flowing into the lagoon (Fig. 1) (Durand, 2003).

In the archeological record, evidence for grape cultivation occurs from the Iron Age and accounts for the presence of Vitis pollen after 2500 cal BP (Alonso et al., 2007, 2008). Earlier, Vitis pollen grains may originate from wild grapes naturally growing in this area (Ali et al., 2008). Moreover, archeobotanical studies demonstrate that Neolithic and Bronze Age populations were gathering wild grapes and thus may have favored this taxon near the lagoon (Alonso et al., 2007, 2008; Chabal and Terral, 2007).

Before Classical Antiquity, it is assumed that the few Olea pollen grains found at Palavas (Fig. 2) refer to wild olive trees probably present in narrow thermomediterranean coastal areas. The later continuous record of Olea since Classical Antiquity (Fig. 2) is probably related to its introduction and cultivation by the Romans in southern France (Leveau, 2003). However, at Palavas, low proportions of Olea are recorded throughout the first millennium AD. Indeed, various archeological archives attest to the limited cultivation of olives in this area during the Roman period (Alonso et al., 2008; Leveau, 2003). Historical studies demonstrate that olive cultivation developed later in Languedoc, during the High Middle Ages (Leveau, 2003), in agreement with our pollen data (Fig. 2).

During the medieval period, simultaneous increases in Juglans and Castanea with Olea (Fig. 2) suggest an expansion of tree cultivation and corroborate the major influence of human activity on the environment in the Palavas region around $1000 \mathrm{AD}$.

\subsection{Reforestation during the last century}

At the beginning of the 20th century, the major reforestation with evergreen Quercus and Pinus recorded at Palavas is consistent with land registry data which indicate that forest cover increased from 80000 to 190000 ha between 1900 
and $2000 \mathrm{AD}$ in the French department of Hérault (Koerner et al., 2000). This change corresponds to the well-known industrial revolution, which resulted in migration of rural populations towards cities, and to widespread land abandonment. The mechanization of farming at the beginning of the 20th century amplified the abandonment of land unsuitable for modern agriculture, which was consequently recolonized by the forest.

\subsection{The deciduous forest replacement}

During the 20th-century reforestation, Pinus and evergreen Quercus proportions rise while deciduous Quercus proportions remain stable (Pal-VIII in Figs. 2 and 3). The expansion of evergreen Quercus and Pinus forest has no equivalent in the past. Indeed, at the end of the 9th century, after 100 years of reforestation the dominant taxon was still deciduous Quercus.

Differences between the reforestation dynamic of the 20th century compared to that of the 9th century might be related to the late Holocene aridification. During the last 1000 years, the enhanced dryness could have favored Pinus and evergreen Quercus. However, ecological studies in southern France demonstrate that in the near future Quercus pubescens, the present deciduous species in this area, could replace Quercus ilex and Pinus halepensis in many places (Bacilieri et al., 1993). Indeed, Pinus halepensis is a pioneer species of Mediterranean ecological successions that will typically be replaced by $Q$. ilex. Furthermore, it is known that $Q$. ilex inhibits the germination of its own seeds and not those of $Q$. pubescens (Barbero et al., 1990; Bran et al., 1990; Bacilieri et al., 1993; Li and Romane, 1997). Such processes of auto-allelopathy enable the replacement of $Q$. ilex by $Q$. pubescens. Vegetation surveys over several decades show that without any human disturbances, the proportions of $Q$. pubescens in the vegetation increase (Barbero et al., 1990).

Therefore, the Pinus and evergreen Quercus expansion is more likely related to enhanced anthropogenic impact on forests. Indeed, P. halepensis was widely planted (Barbero et al., 1988) and coppicing was widespread in southern France during the first half of the 20th century (Ducrey, 1988; Barbero et al., 1990; Koerner et al., 2000). As a consequence of coppicing, $Q$. pubescens has been supplanted by $Q$. ilex as the deciduous oak is less efficient at resprouting and thus less resilient to high-frequency disturbances such as forest harvesting compared to the evergreen oak (Barbero et al., 1990). Similar situations where the present Mediterranean vegetation is strongly shaped by recent human activity more than climatic factors are also recorded in Italy (Henne et al., 2015).

\section{Conclusion}

Based on the Palavas pollen record, vegetation changes highlighted during the last $4600 \mathrm{cal} \mathrm{BP}$ are interpreted in terms of climate and/or human influence and indicate the following:

- a clear aridification trend from 4600 cal BP to the present day expressed through the range contraction toward the north in Fagus and Abies.

- three short arid events which interrupt the general trend at 4600-4300, 2800-2400 and 1300-1100 cal BP. These events coincide in time with rapid climatic events that occurred during the late Holocene. The closeness in time of arid events with high storm activity periods within the Bond windows, suggests a two-phase pattern with a humid phase followed by an arid one.

Oscillations of evergreen Quercus representation and arboreal pollen proportions largely correlated with human history. Firstly, farming activity favored evergreen Quercus from the Neolithic onwards, gradually changing the forest composition. Secondly, three deforestation episodes are depicted (1) from the Bronze Age to the end of the Iron Age; (2) at the transition between Classical Antiquity and the Middle Ages; and (3) during the 9th century. Between the first two episodes, Classical Antiquity is characterized by a major reforestation related to the concentration of rural activity and populations in plains, leading to forest recovery in the mountains. At the beginning of the 20th century, a new reforestation occurred due to farming mechanization. Evergreen Quercus and Pinus expansion is related to coppicing and the increase in fire frequency.

\section{The Supplement related to this article is available online at doi:10.5194/cp-11-1769-2015-supplement.}

Acknowledgements. This research was funded by MISTRALS/PALEOMEX meta-program, the CNRS and the French Museum of National History (MNHN). Radiocarbon dating was performed at the LMC14 laboratory as a part of the French ARTEMIS program. Some samples were processed in the IPHES laboratory of palynology (Tarragona, Spain), and we are grateful to Francesc Burjachs Casas, Isabel Expósito Barea and Ethel Allué for their welcome and their help. We thank Michelle Farrell for English corrections. We are grateful to Bruno Cinotti for sharing unpublished data about estimated forest cover using land register. We thank the reviewers for their helpful comments in improving the manuscript.

Edited by: J. Guiot 


\section{References}

Ali, A. A., Roiron, P., Chabal, L., Ambert, P., Gasco, J., André, J., and Terral, J.-F.: Holocene hydrological and vegetation changes in southern France inferred by the study of an alluvial travertine system (Saint-Guilhem-le-Désert, Hérault), C. R. Geosci., 340, 356-366, doi:10.1016/j.crte.2008.02.001, 2008.

Aloïsi, J.-C., Monaco, A., Planchais, N., Thommeret, J., and Thommeret, Y.: The Holocene transgression in the Golfe du Lion, southwestern France: paleogeographic and paleobotanical evolution, Geogr. Phys. Quatern., 32, 145-162, 1978.

Alonso, N., Buxó, R., and Rovira, N.: Recherches sur l'alimentation végétale et l'agriculture du site de Lattes-Port Ariane: étude des semences et fruits, Lattara, 20, 219-249, 2007.

Alonso, N., Buxó, R., and Rovira, N.: Archéobotanique des semences et des fruits de Lattara: bilan des recherches, La ville portuaire de Lattara (Lattes, Hérault) et son territoire: nouveaux acquis, nouvelles questions, Gallia, 65, 1-8, 2008.

Bacilieri, R., Bouchet, M. A., Bran, D., Grandjanny, M., Maistre, M., Perret, P., and Romane, F.: Germination and regeneration mechanisms in Mediterranean degenerate forests, J. Veg. Sci., 4, 241-246, 1993.

Barbero, M., Loisel, R., and Quézel, P.: Perturbations et incendies en région méditerranéenne française, in: Homenaje a Pedro Montserrat, Instituto de Estudios Altoaragoneses, 409-420, 1988.

Barbero, M., Bonin, G., Loisel, R., and Quézel, P.: Changes and disturbances of forest ecosystems caused by human activities in the western part of the Mediterranean basin, Plant Ecol., 87, 151173, 1990.

Bennett, K. D.: PSIMPOLL: a quickBASIC program that generates PostScript page description files of pollen diagrams, INQUA Commission for the study of the Holocene: working group on data handling methods newsletter, 8, 11-12, 1992.

Berglund, B. and Ralska-Jasiewiczowa, M.: Pollen analysis and pollen diagrams, Handbook of Holocene palaeoecology and palaeohydrology, Vol. 455, p. 484, 1986.

Beug, H. J.: Leitfaden der Pollenbestimmung für Mitteleuropa und angrenzende Gebiete, Verlag Dr. Friedrich Pfeif, München, 542 pp., 2004.

Blaauw, M.: Methods and code for "classical" age-modelling of radiocarbon sequences, Quaternary Geochronol., 5, 512-518, 2010.

Bond, G., Kromer, B., Beer, J., Muscheler, R., Evans, M. N., Showers, W., Hoffmann, S., Lotti-Bond, R., Hajdas, I., and Bonani, G.: Persistent solar influence on North Atlantic climate during the Holocene, Science, 294, 2130-2136, 2001.

Bran, D., Lobreaux, O., Maistre, M., Perret, P., and Romane, F.: Germination of Quercus ilex and $Q$. pubescens in a $Q$. ilex coppice, Vegetatio, 87, 45-50, 1990.

Britton, C., Chabal, L., Pagès, G., and Schneider, L.: Approche interdisciplinaire d'un bois méditerranéen entre la fin de l'antiquité et la fin du Moyen Âge, Saugras et Aniane, Valène et Montpellier, Médiévales, Langues, Textes, Histoire, 53, 65-80, 2007.

Broström, A., Nielsen, A. B., Gaillard, M.-J., Hjelle, K., Mazier, F., Binney, H., Bunting, J., Fyfe, R., Meltsov, V., and Poska, A.: Pollen productivity estimates of key European plant taxa for quantitative reconstruction of past vegetation: a review, Veg. Hist. Archaeobot., 17, 461-478, 2008.
Cacho, I., Grimalt, J. O., Canals, M., Sbaffi, L., Shackleton, N. J., Schönfeld, J., and Zahn, R.: Variability of the western Mediterranean Sea surface temperature during the last 25,000 years and its connection with the Northern Hemisphere climatic changes, Paleoceanography, 16, 40-52, 2001.

Carrión, J. S.: Patterns and processes of Late Quaternary environmental change in a montane region of southwestern Europe, Quaternary Sci. Rev., 21, 2047-2066, 2002.

Carrión, J. S., Sánchez-Gómez, P., Mota, J. F., Yll, R., and Chaín, C.: Holocene vegetation dynamics, fire and grazing in the Sierra de Gádor, southern Spain, Holocene, 13, 839-849, 2003.

Cavero, J. and Chabal, L.: Paléogéographie, dynamique forestière et peuplement d'un milieu lagunaire. L'étang de l'Or (Hérault) àla fin de la Préhistoire, Quaternaire, Revue de l'Association française pour l'étude du Quaternaire, 21, 13-26, 2010.

Chabal, L.: Étude anthracologique de Lattes Port Ariane: forêts littorales en Bas Languedoc depuis le Néolithique moyen, edited by: Daveau, I., Port Ariane (Lattes, Hérault), construction deltaïque et utilisation d'une zone humide lors des six derniers millénaires, Lattara, 20, 183-198, 2007.

Chabal, L. and Terral, J.-F.: Le bois de vigne de Port Ariane: étude de racines de vigne alto-médiévales, Lattara, 20, 1-7, 2007.

Combourieu-Nebout, N., Peyron, O., Dormoy, I., Desprat, S., Beaudouin, C., Kotthoff, U., and Marret, F.: Rapid climatic variability in the west Mediterranean during the last 25000 years from high resolution pollen data, Clim. Past, 5, 503-521, doi:10.5194/cp5-503-2009, 2009.

Combourieu-Nebout, N., Peyron, O., Bout-Roumazeilles, V., Goring, S., Dormoy, I., Joannin, S., Sadori, L., Siani, G., and Magny, M.: Holocene vegetation and climate changes in the central Mediterranean inferred from a high-resolution marine pollen record (Adriatic Sea), Clim. Past, 9, 2023-2042, doi:10.5194/cp9-2023-2013, 2013.

De Beaulieu, J.-L., Miras, Y., Andrieu-Ponel, V., and Guiter, F.: Vegetation dynamics in north-western Mediterranean regions: instability of the Mediterranean bioclimate, Plant Biosyst., 139, 114-126, 2005.

Debret, M., Bout-Roumazeilles, V., Grousset, F., Desmet, M., McManus, J. F., Massei, N., Sebag, D., Petit, J.-R., Copard, Y., and Trentesaux, A.: The origin of the 1500-year climate cycles in Holocene North-Atlantic records, Clim. Past, 3, 569-575, doi:10.5194/cp-3-569-2007, 2007.

Delhon, C. and Thiébault, S.: The migration of beech (Fagus sylvatica L.) up the Rhone: the Mediterranean history of a "mountain" species, Veg. Hist. Archaeobot., 14, 119-132, 2005.

Desprat, S., Combourieu-Nebout, N., Essallami, L., Sicre, M. A., Dormoy, I., Peyron, O., Siani, G., Bout Roumazeilles, V., and Turon, J. L.: Deglacial and Holocene vegetation and climatic changes in the southern Central Mediterranean from a direct land-sea correlation, Clim. Past, 9, 767-787, doi:10.5194/cp-9767-2013, 2013.

Dezileau, L., Sabatier, P., Blanchemanche, P., Joly, B., Swingedouw, D., Cassou, C., Castaings, J., Martinez, P., and Von Grafenstein, U.: Intense storm activity during the Little Ice Age on the French Mediterranean coast, Palaeogeogr. Palaeocl., 299, 289-297, 2011.

Ducrey, M.: Sylviculture des taillis de Chêne vert pratiques traditionnelles et problématique des recherches récentes, ENGREF, 
Ecole nationale du génie rural, des eaux et des forêts, Nancy, France, 1988.

Durand, A.: Les paysages médiévaux du Languedoc: Xe-XIIe siècles, Presses Univ. du Mirail, 2003.

Faegri, K. and Iversen, J.: Textbook of pollen analysis, 4th Edn., edited by: Faegri, K., Kaland, P. E., and Krzywinski, K., Wiley, Chichester, 1989.

IPCC: Summary for policymakers, in: Climate Change 2014: Impacts, Adaptation, and Vulnerability. Part A: Global and Sectoral Aspects. Contribution of Working Group II to the Fifth Assessment Report of the Intergovernmental Panel on Climate Change, edited by: Field, C. B., Barros, V. R., Dokken, D. J., Mach, K. J., Mastrandrea, M. D., Bilir, T. E., Chatterjee, M., Ebi, K. L., Estrada, Y. O., Genova, R. C., Girma, B., Kissel, E. S., Levy, A. N., MacCracken, S., Mastrandrea, P. R., and White, L. L., Cambridge University Press, Cambridge, United Kingdom and New York, NY, USA, 1-32, 2014.

Figueiral, I., Jung, C., Martin, S., Tardy, C., Compan, M., Pallier, C., Pomaredes, H., and Fabre, L.: La perception des paysages et des agro-systèmes antiques de la moyenne vallée de l'Hérault. Apports des biomarqueurs à l' archéologie préventive, in La perception des paysages et des agro-systèmes antiques de la moyenne vallée de l'Hérault. Apports des biomarqueurs à l'archéologie préventive, 415-430, APDCA, 2010.

Fletcher, W. J. and Zielhofer, C.: Fragility of Western Mediterranean landscapes during Holocene Rapid Climate Changes, CATENA, 103, 16-29, doi:10.1016/j.catena.2011.05.001, 2013.

Fletcher, W. J., Boski, T., and Moura, D.: Palynological evidence for environmental and climatic change in the lower Guadiana valley, Portugal, during the last 13000 years, Holocene, 17, 481-494, 2007.

Frigola, J., Moreno, A., Cacho, I., Canals, M., Sierro, F. J., Flores, J. A., Grimalt, J. O., Hodell, D. A., and Curtis, J. H.: Holocene climate variability in the western Mediterranean region from a deepwater sediment record, Paleoceanography, 22, PA2209, doi:10.1029/2006PA001307, 2007.

Gasco, J.: L'âge du Bronze dans le sud de la France, in: La France préhistorique, un essai d'histoire, Editions Gallimard, France, 2010.

Giraudi, C.: The Apennine glaciations in Italy, Quaternary glaciations-extent and chronology, part I: Europe, Developments in quaternary science, 2, 215-224, 2004.

Giraudi, C.: Middle to Late Holocene glacial variations, periglacial processes and alluvial sedimentation on the higher Apennine massifs (Italy), Quaternary Res., 64, 176-184, 2005.

Giraudi, C., Magny, M., Zanchetta, G., and Drysdale, R. N.: The Holocene climatic evolution of Mediterranean Italy: A review of the continental geological data, Holocene, 21, 105-115, 2011.

Henne, P. D., Elkin, C., Franke, J., Colombaroli, D., Calò, C., La Mantia, T., Pasta, S., Conedera, M., Dermody, O., and Tinner, W.: Reviving extinct Mediterranean forest communities may improve ecosystem potential in a warmer future, Front. Ecol. Environ., 13, 356-362, 2015.

Jallot, L.: La fin du Néolithique dans la moitié sud de la France, in La France préhistorique, un essai d'histoire, Editions Gallimard, France, 2010.

Jallot, L.: Frontières, stabilités, emprunts et dynamique géoculturelle en Languedoc méditerranéen au Néolithique final (3400-
2300 av. J.C.), in Actes des èmes Rencontres Méridionales de Préhistoire Récente, 87-119, 2011.

Jalut, G.: Analyse pollinique de sédiments holocènes de l'étang de Capestang (Hérault), Temps et espace dans le bassin de l'Aude du Néolithique à l'Age du Fer, 293-302, 1995.

Jalut, G., Amat, A. E., Bonnet, L., Gauquelin, T., and Fontugne, M.: Holocene climatic changes in the Western Mediterranean, from south-east France to south-east Spain, Palaeogeogr. Palaeocl., 160, 255-290, 2000.

Jalut, G., Dedoubat, J. J., Fontugne, M., and Otto, T.: Holocene circum-Mediterranean vegetation changes: climate forcing and human impact, Quaternary Int., 200, 4-18, 2009.

Janin, T.: L'âge du fer dans le sud de la France, in La France préhistorique, un essai d'histoire, 461-486, Editions Gallimard, France, 2010.

Jiménez-Espejo, F. J., García-Alix, A., Jiménez-Moreno, G., Rodrigo-Gámiz, M., Anderson, R. S., Rodríguez-Tovar, F. J., Martínez-Ruiz, F., Giralt, S., Huertas, A. D. and PardoIgúzquiza, E.: Saharan aeolian input and effective humidity variations over western Europe during the Holocene from a high altitude record, Chem. Geol., 374, 1-12, 2014.

Jiménez-Moreno, G., Rodríguez-Ramírez, A., Pérez-Asensio, J. N., Carrión, J. S., López-Sáez, J. A., Villarías-Robles, J. J., Celestino-Pérez, S., Cerrillo-Cuenca, E., León, Á., and Contreras, C.: Impact of late-Holocene aridification trend, climate variability and geodynamic control on the environment from a coastal area in SW Spain, Holocene, 25, 607-617, 2015.

Jorda, C., Chabal, L., and Blanchemanche, P.: Lattara entre terres et eaux, Gallia, 65, 1-230, 2008.

Kaplan, M.: Le Moyen Âge, IV'-X siècles, Paris, Bréal, 1994.

Koerner, W., Cinotti, B., Jussy, J.-H., and Benoît, M.: Evolution des surfaces boisées en France depuis le début du XIXe siècle: identification et localisation des boisements des territoires agricoles abandonnés, Revue forestière française, 52, 249-270, 2000.

Kotthoff, U., Müller, U. C., Pross, J., Schmiedl, G., Lawson, I. T., van de Schootbrugge, B., and Schulz, H.: Lateglacial and Holocene vegetation dynamics in the Aegean region: an integrated view based on pollen data from marine and terrestrial archives, Holocene, 18, 1019-1032, 2008.

Leveau, P.: L'oléiculture en Gaule Narbonnaise: données archéologiques et paléoenvironnemtales. PrésentationInterprétation, Revue archéologique de Picardie, 1, 299-308, 2003.

Li, J. and Romane, F. J.: Effects of germination inhibition on the dynamics of Quercus ilex stands, J. Veg. Sci., 8, 287-294, 1997.

Magny, M.: Holocene climate variability as reflected by midEuropean lake-level fluctuations and its probable impact on prehistoric human settlements, Quaternary Int., 113, 65-79, 2004.

Magny, M.: Orbital, ice-sheet, and possible solar forcing of Holocene lake-level fluctuations in west-central Europe: a comment on Bleicher, Holocene, 23, 1202-1212, 2013.

Magny, M., Miramont, C., and Sivan, O.: Assessment of the impact of climate and anthropogenic factors on Holocene Mediterranean vegetation in Europe on the basis of palaeohydrological records, Palaeogeogr. Palaeocl., 186, 47-59, 2002.

Magny, M., Joannin, S., Galop, D., Vannière, B., Haas, J. N., Bassetti, M., Bellintani, P., Scandolari, R., and Desmet, M.: Holocene palaeohydrological changes in the northern Mediter- 
ranean borderlands as reflected by the lake-level record of Lake Ledro, northeastern Italy, Quaternary Res., 77, 382-396, 2012.

Magny, M., Combourieu-Nebout, N., de Beaulieu, J. L., BoutRoumazeilles, V., Colombaroli, D., Desprat, S., Francke, A., Joannin, S., Ortu, E., Peyron, O., Revel, M., Sadori, L., Siani, G., Sicre, M. A., Samartin, S., Simonneau, A., Tinner, W., Vannière, B., Wagner, B., Zanchetta, G., Anselmetti, F., Brugiapaglia, E., Chapron, E., Debret, M., Desmet, M., Didier, J., Essallami, L., Galop, D., Gilli, A., Haas, J. N., Kallel, N., Millet, L., Stock, A., Turon, J. L., and Wirth, S.: North-south palaeohydrological contrasts in the central Mediterranean during the Holocene: tentative synthesis and working hypotheses, Clim. Past, 9, 20432071, doi:10.5194/cp-9-2043-2013, 2013.

Marchal, O., Cacho, I., Stocker, T. F., Grimalt, J. O., Calvo, E., Martrat, B., Shackleton, N., Vautravers, M., Cortijo, E., and van Kreveld, S.: Apparent long-term cooling of the sea surface in the northeast Atlantic and Mediterranean during the Holocene, Quaternary Sci. Rev., 21, 455-483, 2002.

Naughton, F., Goñi, M. S., Kageyama, M., Bard, E., Duprat, J., Cortijo, E., Desprat, S., Malaizé, B., Joly, C., and Rostek, F.: Wet to dry climatic trend in north-western Iberia within Heinrich events, Earth Planet. Sc. Lett., 284, 329-342, 2009.

Ouzoulias, P.: La géographie de la villa dans les Gaules romaines?: quelques observations, in: Actes du colloque international AGER IX, 253-268, 2013.

Pérez-Obiol, R., Jalut, G., Julià, R., Pèlachs, A., Iriarte, M. J., Otto, T., and Hernández-Beloqui, B.: Mid-Holocene vegetation and climatic history of the Iberian Peninsula, Holocene, 21, 75-93, 2011

Planchais, N.: Palynologie lagunaire de l'étang de Mauguio, Paléoenvironnement végétal et évolution anthropique, Pollen et spores, 1, 93-118, 1982.

Planchais, N.: Impact de l'homme lors du remplissage de l'estuaire du Lez (Palavas, Hérault) mis en évidence par l'analyse pollinique, Pollen et spores, 29, 73-88, 1987.

Puertas, O.: Évolution holocène de la végétation en bordure de l'étang de Méjean: analyse pollinique du sondage d'Embouchac (Lattes, Hérault, France) [Holocene vegetation dynamic on the edge of the Méjean lagune; pollen analysis of Embouchac boring (Lattes, Hérault, France)], Quaternaire, 9, 79-89, 1998.

Puertas, O.: Premiers indices polliniques de néolithisation dans la plaine littorale de Montpellier (Hérault, France), Bulletin de la Société préhistorique française, 96, 15-20, 1999.

Punt, W.: The Northwest European Pollen Flora (NEPF) Vol I (1976), Vol II (1980), Vol III (1981), Vol IV (1984) Vol V (1988), Vol VI (1991), Vol VII (1996), Elsevier, Amsterdam, 1976.

Quezel, P.: La région méditerranéenne française et ses essences forestières, signification écologique dans le contexte circumméditerranéen, Forêt Méd, 1, 7-18, 1979.

Reille, M.: Pollen et Spores d'Europe et d'Afric du Nort, Mar-seille: Laboratoire de Botanique historique et Palynologie, 520 pp., 1992.

Reille, M. and Pons, A.: The ecological significance of sclerophyllous oak forests in the western part of the Mediterranean basin: a note on pollen analytical data, in Quercus ilex L. ecosystems: function, dynamics and management, 13-17, Springer, 1992.

Reimer, P. J., Baillie, M. G., Bard, E., Bayliss, A., Beck, J. W., Blackwell, P. G., Bronk, R. C., Buck, C. E., Burr, G. S., and Edwards, R. L.: IntCa109 and Marine09 radiocarbon age calibra- tion curves, 0-50,000 years cal BP, Radiocarbon, 51, 1111-1150, 2009.

Roberts, N., Jones, M. D., Benkaddour, A., Eastwood, W. J., Filippi, M. L., Frogley, M. R., Lamb, H. F., Leng, M. J., Reed, J. M., and Stein, M.: Stable isotope records of Late Quaternary climate and hydrology from Mediterranean lakes: the ISOMED synthesis, Quaternary Sci. Rev., 27, 2426-2441, 2008.

Roberts, N., Eastwood, W. J., Kuzucuoglu, C., Fiorentino, G., and Caracuta, V.: Climatic, vegetation and cultural change in the eastern Mediterranean during the mid-Holocene environmental transition, Holocene, 21, 147-162, 2011.

Sabatier, P. and Dezileau, L.: Archives sédimentaires dans les lagunes du Golfe d'Aigues-Mortes. Estimation de l'aléa de tempête depuis 2000 ans, Quaternaire, Revue de l'Association française pour l'étude du Quaternaire, 21, 5-11, 2010.

Sabatier, P., Dezileau, L., Colin, C., Briqueu, L., Bouchette, F., Martinez, P., Siani, G., Raynal, O., and Von Grafenstein, U.: 7000 years of paleostorm activity in the NW Mediterranean Sea in response to Holocene climate events, Quaternary Res., 77, 1-11, 2012.

Sadori, L., Jahns, S., and Peyron, O.: Mid-Holocene vegetation history of the central Mediterranean, Holocene, 21, 117-129, 2011.

Sadori, L., Giardini, M., Gliozzi, E., Mazzini, I., Sulpizio, R., van Welden, A., and Zanchetta, G.: Vegetation, climate and environmental history of the last 4500 years at lake Shkodra (Albania/Montenegro), Holocene, 25, 435-444, 2014.

Schmiedl, G., Kuhnt, T., Ehrmann, W., Emeis, K.-C., Hamann, Y., Kotthoff, U., Dulski, P., and Pross, J.: Climatic forcing of eastern Mediterranean deep-water formation and benthic ecosystems during the past 22000 years, Quaternary Sci. Rev., 29, 30063020, 2010.

Schneider, L.: Aux marges méditerranéennes de la Gaule mérovingienne. Les cadres politiques et ecclésiastiques de l'ancienne Narbonnaise Iere entre Antiquité et Moyen Age (VeIXe siècles), L'espace du diocèse, Genèse d'un terrioire dans l'occident médiéval (Ve-XIIIe siècle), 69-95, 2008.

Schneider, L., Fauduet, I., and Odenhardt-Donvez, I.: Structures du peuplement et formes de l'habitat dans les campagnes du sud-est de la France de l'Antiquité au Moyen Âge (IVe-VIIIes.): essai de synthèse, Gallia, 64, 11-56, 2007.

Sorrel, P., Tessier, B., Demory, F., Delsinne, N., and Mouazé, D.: Evidence for millennial-scale climatic events in the sedimentary infilling of a macrotidal estuarine system, the Seine estuary (NW France), Quaternary Sci. Rev., 28, 499-516, 2009.

Stockmarr, J.: Tablets with spores used in absolute pollen analysis, Pollen et spores, XIII, 615-621, 1971.

Sugita, S.: A model of pollen source area for an entire lake surface, Quaternary Res., 39, 239-244, 1993.

Tinner, W., van Leeuwen, J. F., Colombaroli, D., Vescovi, E., Van der Knaap, W. O., Henne, P. D., Pasta, S., D'Angelo, S., and La Mantia, T.: Holocene environmental and climatic changes at Gorgo Basso, a coastal lake in southern Sicily, Italy, Quaternary Sci. Rev., 28, 1498-1510, 2009.

Triat-Laval, H.: Contribution pollenanalytique à l'histoire tardipostglaciaire de la végétation de la Basse Vallée du Rhône, Université d'Aix-Marseille III, 1978.

Trouet, V., Scourse, J. D., and Raible, C. C.: North Atlantic storminess and Atlantic Meridional Overturning Circulation during 
the last Millennium: Reconciling contradictory proxy records of NAO variability, Global Planet. Change, 84, 48-55, 2012.

Vaquer, J.: Le Néolithique moyen en France, cultures et intéractions (4600-3500 av. J.C.), in La France préhistorique, un essai d'histoire, 2010.
Zazo, C., Mercier, N., Silva, P. G., Dabrio, C. J., Goy, J. L., Roquero, E., Soler, V., Borja, F., Lario, J., and Polo, D.: Landscape evolution and geodynamic controls in the Gulf of Cadiz (Huelva coast, SW Spain) during the Late Quaternary, Geomorphology, 68, 269-290, 2005. 